
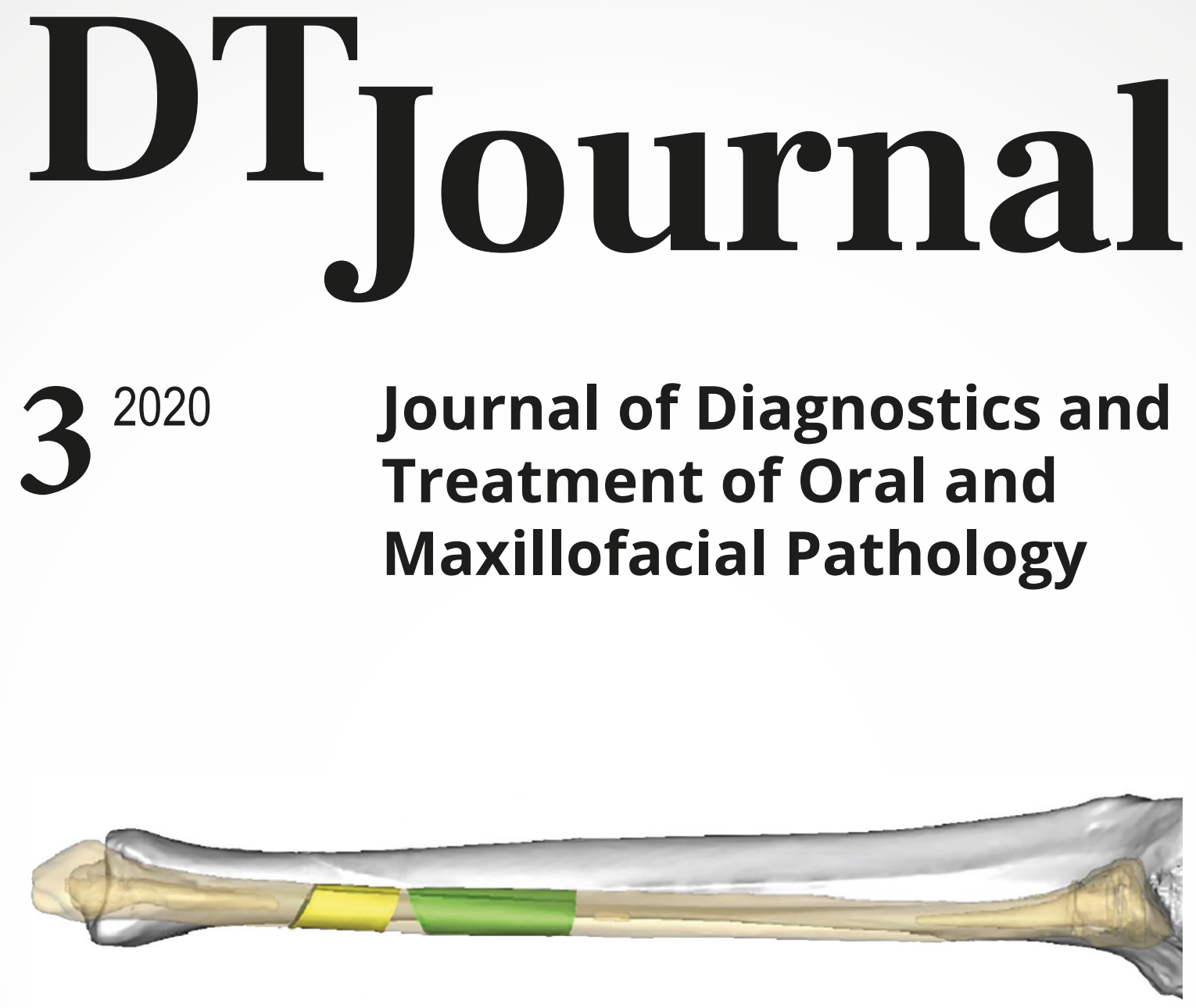

Editors

Oleksii Tymofieiev • Rui Fernandes

(Kyiv, Ukraine • Jacksonville, FL, USA)
Official Journal of the

Ukrainian Association for

Maxillofacial and Oral Surgeons

DTJournal.org 

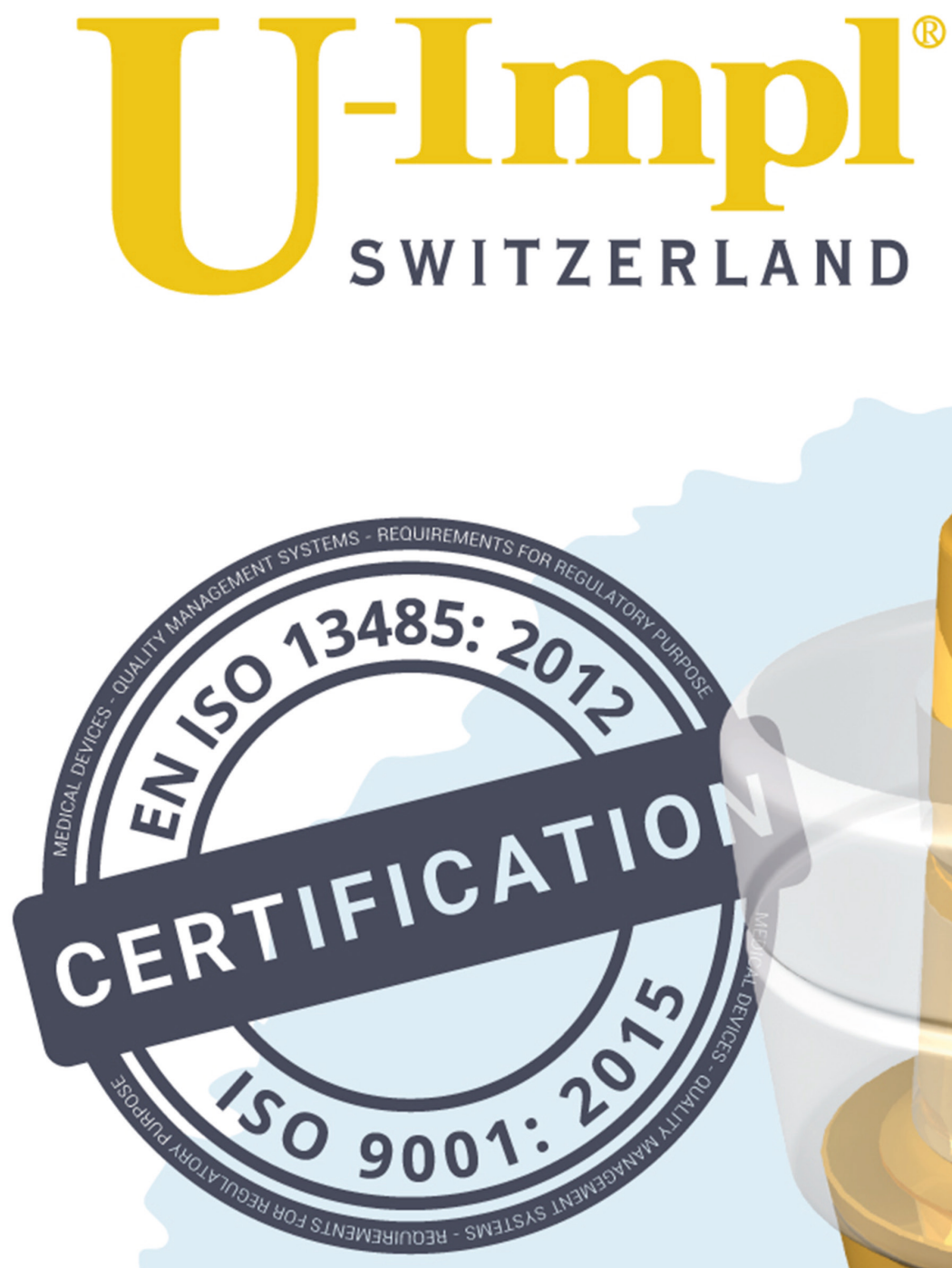

№ R3M 804252 B2

Сертифікат відповідності технічного регламенту щодо медичних виробів 


\section{About the Journal: Aims and Scope

\section{Official Title}

Journal of Diagnostics and Treatment of Oral and Maxillofacial Pathology

\section{Standard Abbreviation: ISO 4}

J. Diagn. Treat. Oral Maxillofac. Pathol.

\section{International Standard Serial Number (ISSN) \\ Print ISSN 2519-2086 | Online ISSN 2522-1965}

\section{Aims \& Scope}

This is a monthly peer-reviewed oral and maxillofacial surgery journal focused on: Microvascular and jaw reconstructive surgery, dental implants, salivary gland tumors/diseases, TMJ lesions, virtual surgical planning, implementation of ultrasonography into the practice of oral and maxillofacial surgeons.

\section{Editorial Board (EB) Composition}

- EB shows significant geographic diversity representing 24 opinion leaders from 13 countries: Brazil, Canada, Colombia, Greece, Hong Kong (SAR, China), India, Israel, Italy, Slovak Republic, Spain, Ukraine, United Arab Emirates, and United States.

- The majority of the EB Members have a discernible publication history in Scopus, Web of Science, and journals with a high impact factor.

- The publication records of all EB members are consistent with the stated scope and published content of the journal.

- The journal has a several full-time professional editors.

\section{Frequency}

12 print/online issues a year (from January 2020)

\section{Publication History}

2017: 4 issues a year

2018: 4 issues a year

2019: 10 issues a year

2020: 12 issues a year

\section{Publishing Model}

Journal combines a hybrid and delayed open access publishing models. The articles of all types, except Editorials, are immediately in open access. Editorials became an open access publication too after 3-month embargo period.

\section{Article Processing Charge (APC)}

During hard times of Covid-19 pandemic our journal trying to support authors by reducing the APC by $50 \%$. And by the end of August 2020 the APC will be 100 USD and 50 USD (excluding taxes) depending on the article's type. Details at website: dtjournal.org.
12 Types of Articles Currently Published by the Journal Editorials/Guest Editorials, Images in Oral \& Maxillofacial Surgery, Case Reports/Case Series, Original Articles, Review Articles, Discussions, Paper Scans (synonyms: Review of Articles, Literature Scan), Book Scans (synonym: Book Reviews), Letters to the Editor (synonym: Letters), and Viewpoints.

\section{Registration: Ministry of Justice of Ukraine}

Registration: July 28, 2016

Re-Registration: May 21, 2019 (Certificate: КВ \# 23999-13839ПР)

\section{Co-Founders}

1. Shupyk National Medical Academy of Postgraduate Education.

2. Private Higher Educational Establishment "Kyiv Medical University."

3. OMF Publishing, Limited Liability Company.

\section{Publisher}

OMF Publishing, LLC is an academic publisher focused on medical and linguistic sciences.

Address: 13-A Simferopolska Street, Office 121, Kyiv 02096, Ukraine. Tel.: +380632931813.

\section{Crossref Membership}

OMF Publishing, LLC is a member of Publishers International Linking Association, Inc. which doing business as a Crossref. OMF Publishing`s active membership: From February 2017 to present.

\section{Official Journal of}

Ukrainian Association for Maxillofacial and Oral Surgeons

\section{Ukrainian Association for Maxillofacial and Oral Surgeons (UAMOS)}

Address: 4-A Profesora Pidvysotskoho Street, Kyiv 01103, Ukraine. Tel., fax: +38 0445283517 .

Website: uamos.org.

\section{Subscription Index}

In Ukraine: 60077 | In Donetsk/Luhansk Regions: 88263. See page A5.

\section{(c) 2020 OMF PUBLISHING, LLC}




\section{Editor in Chief \\ Oleksii O. Tymofieiev, ScD \\ (Kyiv, Ukraine) \\ Deputy Editor in Chief}

Rui P. Fernandes, MD, DMD, FACS, FRCS(Ed)

(Jacksonville, Florida, United States)

Section Editors

Bone Augmentation Techniques

Nardy Casap, MD, DMD

(Jerusalem, Israel)

Craniofacial Deformities

Sunil Richardson, MDS

(Nagercoil, Tamil Nadu, India)

Facial Feminization Surgery

Kyle Keojampa, MD, FACS

(Los Angeles, California, United States)

Facial Plastic Surgery

Tirbod Fattahi, MD, DDS, FACS

(Jacksonville, Florida, United States)

Head \& Neck Oncologic Surgery

Todd C. Hanna, MD, DDS, FACS

(New York, New York, United States)
Head \& Neck Radiology

Anil T. Ahuja, MBBS, MD, FRCR, FHKCR, FHKAM

(Hong Kong, SAR, China)

Images in Oral \& Maxillofacial Surgery

Camilo Mosquera, DDS

(Bogotá, D.C., Colombia)

Orthognathic Surgery

Mario Brinhole

(São Paolo, São Paolo, Brazil)

Robotic Surgery

Salam O. Salman, MD, DDS, FACS

(Jacksonville, Florida, United States)

TMJ Lesions/Disorders

Belmiro C. Vasconcelos, DDS, PhD

(Recife, Pernambuco, Brazil)

Editorial Board Members

Oleh M. Antonyshyn, MD, FRCS(C)

(Toronto, Ontario, Canada)

Anthony M. Bunnell, MD, DMD, FACS

(Jacksonville, Florida, United States)

Nur A. Hatab, DMD, PhD

(Ras Al Khaimah, United Arab Emirates)

Andrey V. Kopchak, ScD

(Kyiv, Ukraine)
Olindo Massarelli, MD, PhD, FEBOMFS

(Sassari, Italy)

Daniel Robles Cantero, DDS, MSc (Madrid, Spain)

Peter Stanko, MD, PhD

(Bratislava, Slovak Republic)

Olexander O. Tymofieiev, ScD

(Kyiv, Ukraine)
Natalia O. Ushko, ScD

(Kyiv, Ukraine)

\section{Web \& Social Media Editor}

João L. Monteiro, DDS

(Boston, Massachusetts, United States)
Director, Journal Development Department

Evangelos G. Kilipiris, DMD

(Thessaloniki, Greece | Bratislava, Slovak Republic)
Managing Editor

Ievgen I. Fesenko, PhD

(Kyiv, Ukraine) 


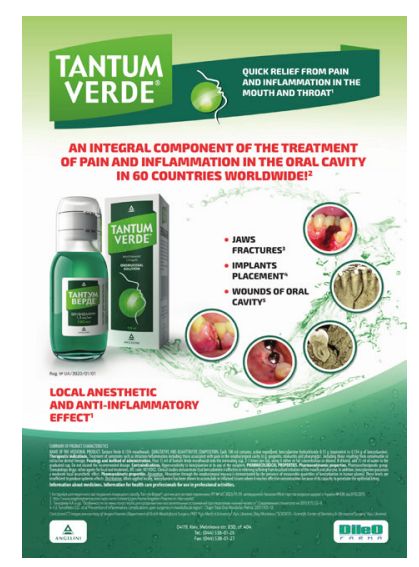

\section{TANTUM VERDE ${ }^{\circledR}$ \\ INFORMATION LEAFLET \\ for the medicinal product}

\section{Composition:}

active substance: benzydamine hydrochloride;

$100 \mathrm{~mL}$ of solution contain benzydamine hydrochloride $0.15 \mathrm{~g}$;

excipients: ethanol 96\%, glycerol, methyl parahydroxybenzoate (E 218), flavor (menthol), saccharin, sodium hydrocarbonate, Polysorbate 20, Quinoline Yellow (E 104), Patent Blue V (E 131), purified water.

Dosage form. Oromucosal solution.

Basic physical and chemical properties: a clear green liquid with a typical mint flavor.

Pharmacotherapeutic group. Dental preparations. Other agents for local oral treatment.

ATC code: A01A D02.

\section{Pharmacological properties.}

Pharmacodynamics.

Benzydamine is a non-steroidal anti-inflammatory drug (NSAID) with analgesic and antiexudative properties.

Clinical studies have shown that benzydamine is effective in the relief of symptoms accompanying localized irritation conditions of the oral cavity and pharynx. Moreover, benzydamine has anti-inflammatory and local analgesic properties, and also exerts a local anesthetic effect on the oral mucosa.

\section{Pharmacokinetics.}

Absorption through the oral and pharyngeal mucosa has been proven by the presence of measurable quantities of benzydamine in human plasma. However, they are insufficient to produce any systemic pharmacological effect. The excretion occurs mainly in urine, mostly as inactive metabolites or conjugated compounds.

When applied locally, benzydamine has been shown to cumulate in inflamed tissues in an effective concentration due to its ability to permeate through the mucous membrane.

\section{Clinical particulars. \\ Indications.}

Symptomatic treatment of oropharyngeal irritation and inflammation; to relieve pain caused by gingivitis, stomatitis, pharyngitis; in dentistry after tooth extraction or as a preventive measure.

\section{Contraindications.}

Hypersensitivity to the active substance or to any other ingredients of the product.

Interaction with other medicinal products and other types of interaction.

No drug interaction studies have been performed.

\section{Warnings and precautions.}

If sensitivity develops with long-term use, the treatment should be discontinued and a doctor should be consulted to get appropriate treatment.

In some patients, buccal/pharyngeal ulceration may be caused by severe pathological processes. Therefore, the patients, whose symptoms worsen or do not improve within 3 days or who appear feverish or develop other symptoms, should seek advice of a physician or a dentist, as appropriate.

Benzydamine is not recommended for use in patients hypersensitive to acetylsalicylic acid or other non-steroidal anti-inflammatory drugs (NSAIDs).

The product can trigger bronchospasm in patients suffering from or with a history of asthma. Such patients should be warned of this.

For athletes: the use of medicinal products containing ethyl alcohol might result in positive antidoping tests considering the limits established by some sports federations. 
Use during pregnancy or breast-feeding

No adequate data are currently available on the use of benzydamine in pregnant and breastfeeding women. Excretion of the product into breast milk has not been studied. The findings of animal studies are insufficient to make any conclusions about the effects of this product during pregnancy and lactation.

The potential risk for humans is unknown.

TANTUM VERDE should not be used during pregnancy or breast-feeding.

Effects on reaction time when driving or using machines When used in recommended doses, the product does not produce any effect on the ability to drive and operate machinery.

\section{Method of administration and doses.}

Pour $15 \mathrm{~mL}$ of TANTUM VERDE solution from the bottle into the measuring cup and gargle with undiluted or diluted product $(15 \mathrm{~mL}$ of the measured solution can be diluted with $15 \mathrm{~mL}$ of water). Gargle 2 or 3 times daily. Do not exceed the recommended dose.

\section{Children.}

The product should not be used in children under 12 years due to a possibility of ingestion of the solution when gargling.

\section{Overdosage.}

No overdose has been reported with benzydamine when used locally. However, it is known that benzydamine, when ingested in high doses (hundreds times higher than those possible with this dosage form), especially in children, can cause agitation, convulsions, tremor, nausea, increased sweating, ataxia, and vomiting. Such acute overdose requires immediate gastric lavage, treatment of fluid/salt imbalance, symptomatic treatment, and adequate hydration.

\section{Adverse reactions.}

Within each frequency group, the undesirable effects are presented in order of their decreasing seriousness.

Adverse reactions are classified according to their frequency: very common $(\geq 1 / 10)$; common $(\geq 1 / 100$ to $<1 / 10)$; uncommon $(\geq 1 / 1,000$ to $<1 / 100)$; rare $(\geq 1 / 10,000$ to $<1 / 1,000)$; very rare $(<1 / 10,000)$; frequency unknown (cannot be estimated from the available data).
Gastrointestinal disorders: rare - burning mouth, dry mouth; unknown - oral hypesthesia, nausea, vomiting, tongue edema and discoloration, dysgeusia.

Immune system disorders: rare - hypersensitivity reaction, unknown - anaphylactic reaction.

Respiratory, thoracic and mediastinal disorders: very rare-laryngospasm; unknown - bronchospasm.

Skin and subcutaneous tissue disorders: uncommon photosensitivity; very rare - angioedema; unknown - rash, pruritus, urticaria.

Nervous system disorders: unknown - dizziness, headache.

TANTUM VERDE contains methyl parahydroxybenzoate, which can cause allergic reactions (including delayed-type reactions).

Shelf life. 4 years.

\section{Storage conditions.}

Do not store above $25^{\circ} \mathrm{C}$. Keep out of reach of children.

\section{Packaging.}

$120 \mathrm{~mL}$ of solution in a bottle with a measuring cup; 1 bottle per cardboard box.

Dispensing category.

Over-the-counter medicinal product.

\section{Manufacturer.}

Aziende Chimiche Riunite Angelini Francesco A.C.R.A.F. S.p.A., Italy.

Location of the manufacturer and its business address. Via Vecchia del Pinocchio, 22 - 60100 Ancona (AN), Italy.

\section{Date of the last revision of the text.}

September 26, 2018.

Information leaflet is

APPROVED by

Order of the

Ministry of Health of Ukraine

No. 636 dated 01.10.2015

Registration Certificate

No. UA/3920/01/01 


\section{Subscription in Ukraine \\ MARCH $2020 \cdot$ VOLUME $4 \cdot$ ISSUE 3}

Frequency of the Journal of Diagnostics and Treatment of Oral and Maxillofacial

Pathology: 12 issues (synonym: numbers) per year.

Subscription index in Ukraine: 60077.

Subscription index for Donetsk and Luhansk Regions: 88263.
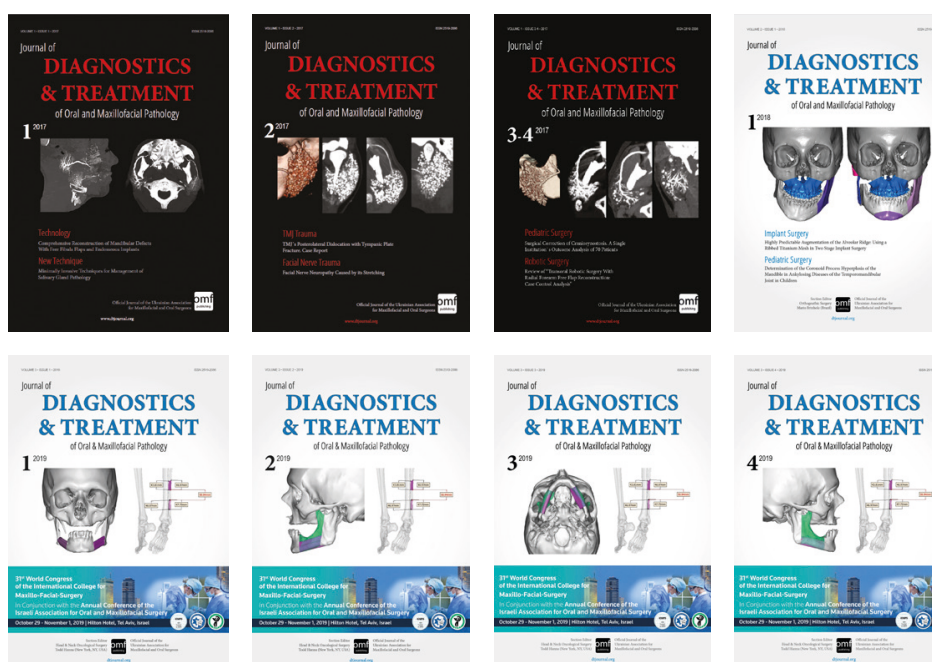

DIAGNOSTICS \& TREATMENT

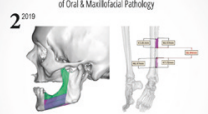

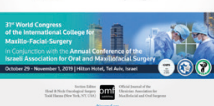

DIAGNOSTICS \& TREATMENT

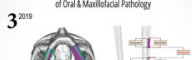
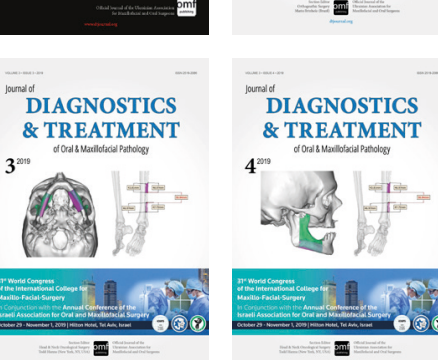

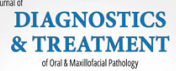

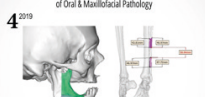
in
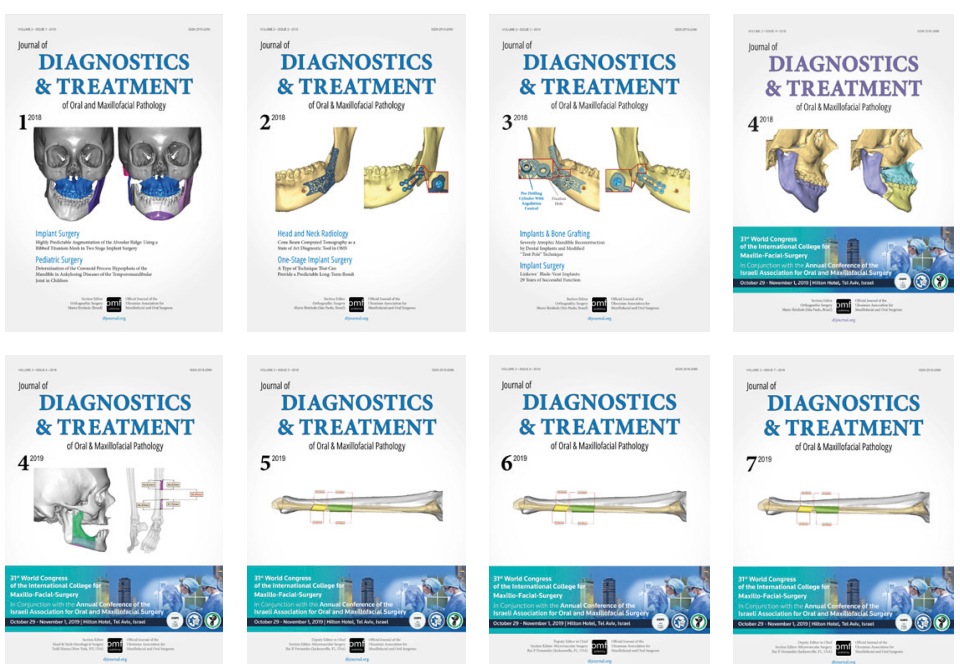

\section{DIAGNOSTICS} \& TREATMENT $7^{\text {xis }}$
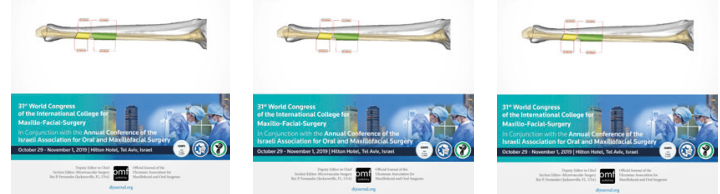

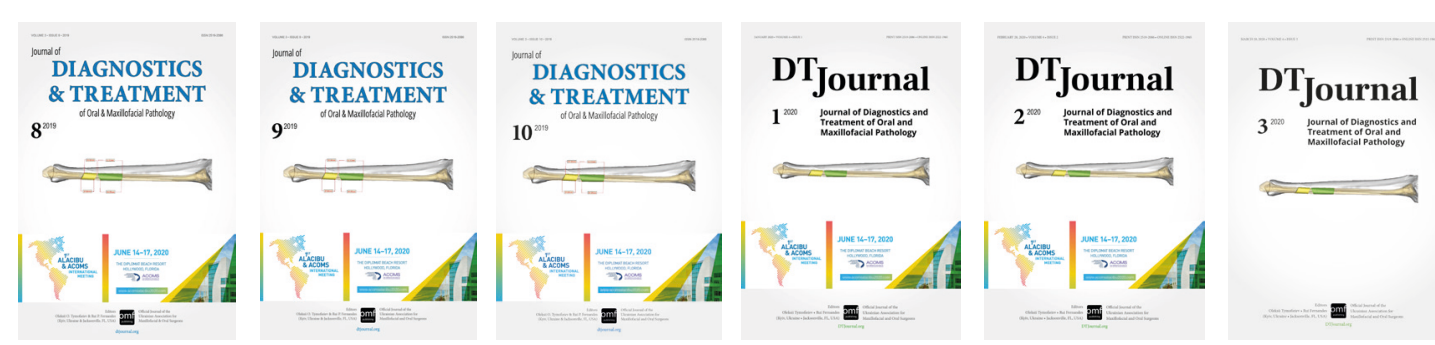

Three ways of individual/institutional subscription of print version of the Journal:

1. At Ukrposhta post at the territory of Ukraine.

2. At the website www.presa.ua.

3. At the website www.dtjournal.org (from September 1, 2020).

\begin{tabular}{|c|c|}
\hline Issues & Fee in 2020 \\
\hline 1 issue & $\$ 4^{12} \mathrm{USD}\left(103^{08} \mathrm{UAH}\right)$ \\
\hline 3 issues & $\$ 12^{36} \mathrm{USD}\left(309^{24} \mathrm{UAH}\right)$ \\
\hline 6 issues & $\$ 24^{73} \mathrm{USD}\left(618^{48} \mathrm{UAH}\right)$ \\
\hline 12 issues & $\$ 49^{47} \mathrm{USD}\left(1,236^{96} \mathrm{UAH}\right)$ \\
\hline
\end{tabular}




\section{Content}

of the Volume 4 • Issue 3 • March 2020

\begin{tabular}{|c|c|c|}
\hline & A1 & About the Journal: Aims and Scope \\
\hline & A2 & Editorial Board \\
\hline & A5 & Subscription in Ukraine \\
\hline & A6 & Content, Courtesy, \& Erratum \\
\hline Editorial & 51 & $\begin{array}{l}\text { Covid-2019 Response: Virtual Educational Process a } \\
\text { and Maxillofacial Surgery using Google Classroom } \\
\text { Oleksii O. Tymofieiev, Natalia O. Ushko, \& Maria O. Yarifa }\end{array}$ \\
\hline $\begin{array}{l}\text { Salivary Glands | Head and } \\
\text { Neck Ultrasound: Case } \\
\text { Report }\end{array}$ & 53 & $\begin{array}{l}\text { Foreign Body Retrograde Migration to the Intr } \\
\text { Submandibular Gland with a Developing of } \\
\text { Sialolithiasis: Analysis of Ultrasonography, Surgery, } \\
\text { during Last } 124 \text { Years } \\
\text { Lilia A. Savchuk \& Oleksandr A. Nozhenko }\end{array}$ \\
\hline $\begin{array}{l}\text { Images in Oral and } \\
\text { Maxillofacial Surgery }\end{array}$ & 60 & $\begin{array}{l}\text { Large Mucocele in the Labial and Buccal Mucosa } \\
\text { Beka Beridze \& Olha S. Cherniak }\end{array}$ \\
\hline $\begin{array}{l}\text { Images in Oral and } \\
\text { Maxillofacial Surgery }\end{array}$ & 62 & $\begin{array}{l}\text { Giant Parotid Pleomorphic Adenoma } \\
\text { Valentyn H. Demidov \& Vasyl A. Rybak }\end{array}$ \\
\hline Post Scriptum Editorial & 64 & $\begin{array}{l}\text { Joining Forces of Two North American Associations } \\
\text { Ievgen I. Fesenko }\end{array}$ \\
\hline
\end{tabular}

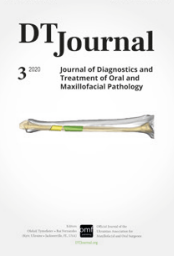

COURTESY

Journal's cover image (virtual surgical planning for a segmental mandibular reconstruction with fibula transplant) is courtesy of Rui P. Fernandes, MD, DMD, FACS, FRCS.

Image was taken from the article: Fernandes RP, Quimby A, Salman S. Comprehensive reconstruction of mandibular defects with free fibula flaps and endosseous implants. J Diagn Treat Oral Maxillofac Pathol 2017;1(1):6-10. 


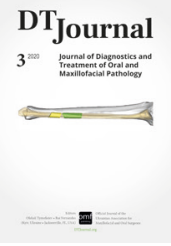

Editorial

\title{
Covid-2019 Response: Virtual Educational Process at the Department of Oral and Maxillofacial Surgery using Google Classroom
}

\author{
Oleksii 0. Tymofieieva, ${ }^{a}$, Natalia 0. Ushko ${ }^{b}, \&$ Maria 0. Yarifa
}

You don't make the timeline; the virus makes the timeline.

-Anthony Fauci

US top infectious-diseases expert

March 25, 2020

Coronavirus disease 2019 (Covid-19) ${ }^{2}$ pandemic led to the severe restrictions around the globe due the extremely rapid spread of the virus and total death number 21,297 people on March 26. ${ }^{3}$ Quarantine measures of the Ukrainian Government became very similar to actions of the other countries. One of which, a closed educational institutions from March $12,{ }^{4}$ created a need to continue education virtually using cutting-edge technologies such as Google Classroom and Google Meet.

Google Classroom, a free web service, was released by the Google LLC in August 2014. "Classroom was created hand-in-hand with teachers to help organize day-to-day tasks, communication, and foster greater collaboration," this is how Google describes the purpose of Classroom`s creation.

Department of Oral and Maxillofacial Surgery, Private Higher Educational Establishment "Kyiv Medical University," Kyiv, Ukraine

a ScD, Professor, Head of the Department

E-mail: tymofeev@gmail.com

${ }^{\mathrm{b}} \mathrm{ScD}$, Professor

${ }^{c} \mathrm{PhD}$, Associate Professor

*Corresponding author's address: 6th floor, Department of Oral and Maxillofacial Surgery. 4-A Profesora Pidvysotskoho Street, Kyiv 01103 Ukraine. Tel., fax: +38 0445283517
Year by year evolution of the Classroom gave its users in 2020 a wide range of tools: Simultaneous usage with Google Docs, Gmail, Google Drive, Sheets and Slides, and even Google Calendar.

A special training course for professors of our university facilitated the effective usage of the Classroom during the quarantine period implementing the e-learning at our Department. A 256 page book "Teaching with Google Classroom," written by Michael Zhang, a certified trainer for Google Apps for Education, gave a deep look on all possibilities of this global e-learning service. ${ }^{6}$

Google Classroom was also launched as a smartphone application in January 2015. Despite of some limitations, at the mobiles we can: 1) create or join a class, 2) make announcements and post comments to assignments, 3) send e-mails to students, 4) access your class's Google Drive, 5) view whether the students have completed assignments or not, 6) reset or disable your class code.

Thus, using all potential of such e-learning services, as Google Classroom, we can effectively

How to cite this article: Tymofieiev OO, Ushko NO, Yarifa MO. Covid-2019 response: virtual educational process at the Department of Oral and Maxillofacial Surgery using Google Classroom. J Diagn Treat Oral Maxillofac Pathol 2020;4(3):51-2.

Paper received 27 January 2020

Accepted 28 March 2020

Available online 31 March 2020

https://dx.doi.org/10.23999/j.dtomp.2020.3.1.

(C) 2020 OMF Publishing, LLC. This is an open access article under the CC BY license (http://creativecommons.org/licenses/by-nc/4.0/). 
deal with a "physical learning" crisis, allowing the students at "surgical dentistry" and "pediatric surgical dentistry" classes to avoid the risk for their lives and to master the curriculum during the pandemic when the timeline is made only by the virus.

\section{REFERENCES}

1. 'You don't make the timeline; the virus makes the timeline, says dr. Anthony Fauci [document on the internet]; March 26, 2020 [cited 2020 Mar 27]. Available from: https://www.marketwatch.com/story/you-dontmake-the-timeline-the-virus-makes-the-timeline-saysdr-anthony-fauci-2020-03-25.

2. WHO. Novel Coronavirus - China [document on the internet]; January 12, 2020 [cited 2020 Mar 25]. Available from: https://www.who.int/csr/don/12-january-2020novel-coronavirus-china/en/.

3. Number of novel coronavirus (COVID-19) deaths worldwide as of March 25, 2020, by country [document on the internet]; March 26, 2020 [cited 2020 Mar 26]. Available from: https://www. statista.com/statistics/1093256/novel-coronavirus2019ncov-deaths-worldwide-by-country/.

4. Ukraine has imposed quarantine amid coronavirus outbreak [document on the internet]; March 12, 2020 [cited 2020 Mar 19]. Available from: http://www. golos.com.ua/article/328891.

5. Classroom [document on the internet]; March 12, 2020 [cited 2020 Mar 20]. Available from: https:// edu.google.com/products/classroom/? modal_ active $=$ none.

6. Zhang M. Teaching with Google Classroom. 1st ed. Birmingham: Packt Publishing; 2016.

7. Cains JT. How to use the Google Classroom mobile app [document on the internet]; [cited 2020 Mar 21]. Available from: https://www.dummies.com/ education/internet-basics/how-to-use-the-googleclassroom-mobile-app/. 


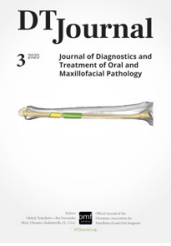

Salivary Glands | Head and Neck Ultrasound: Case Report

\title{
Foreign Body Retrograde Migration to the Intraglandular Duct of the Submandibular Gland with a Developing of Foreign Body-Induced Sialolithiasis: Analysis of Ultrasonography, Surgery, and Literature Published during Last 124 Years
}

\author{
Lilia A. Savchuka \& Oleksandr A. Nozhenkob,*
}

\section{SUMMARY}

We present a unique case of a vegetal foreign body retrograde migration to the intraglandular duct of the submandibular gland with a developing of foreign body-induced sialolithiasis in a 61-year-old woman. Analysis of ultrasound examination and operation are performed. Our foreign body's case represents an intermediate stage of complete sialolith formation around the foreign body nidus (synonym: scaffold). The paper summarizes the analysis of 28 cases with foreign body-induced sialoliths ( 27 cases from literature and a case of our team). Literature review which was based on the studies published during the last 124 years gave a possibility to classify the development of the 'foreign body-induced sialolithiasis' in 4 consecutive stages. Our case of the foreign body-induced sialolithiasis represents a second stage of this pathologic process when nidus is partially covered by calcifications.

a Physician of Ultrasound Investigation, Polyclinic, Kyiv Regional Clinical Hospital, Kyiv, Ukraine.

${ }^{b}$ Oral Surgeon, Center of Maxillofacial Surgery and Dentistry, Kyiv Regional Clinical Hospital, Kyiv, Ukraine.

*Corresponding author address: 1 Bahhovutivska Street, Kyiv 04107, Ukraine. Center of Maxillofacial Surgery and Dentistry, Kyiv Regional Clinical Hospital.

E-mail: alexdent@ukr.net (Oleksandr Nozhenko)
How to cite this article: Savchuk LA, Nozhenko OA. Foreign body retrograde migration to the intraglandular duct of the submandibular gland with a developing of foreign body-induced sialolithiasis: analysis of ultrasonography, surgery, and literature published during last 124 years. J Diagn Treat Oral Maxillofac Pathol 2020;4(3):53-9.

Paper received 12 February 2020

Accepted 14 March 2020

Available online 31 March 2020

https://dx.doi.org/10.23999/j.dtomp.2020.3.2.

(C) 2020 OMF Publishing, LLC. This is an open access article under the CC BY license (http://creativecommons.org/licenses/by-nc/4.0/). 
Obstructive sialadenitis caused by the foreign body intrusion into the duct of the gland can have an acute and chronic clinical course or exacerbation of a chronic form. ${ }^{1}$ Incredibly different foreign bodies inside the Wharton's ducts have been found and reported. Fingernail, ${ }^{2}$ vegetal nidus, ${ }^{3}$ thorn, ${ }^{4}$ piece of hair, ${ }^{5}$ fish bone, ${ }^{6,7}$ metal body, ${ }^{8}$ and other particles are published as foreign bodies of the submandibular gland duct which caused obstructive sialadenitis. In some foreign body cases, for example a fish bone, it was connecting several sialoliths. ${ }^{6}$ Study of Xie et $\mathrm{al}^{7}$ presented 13 patients which had fish bone nidus inside the sialoliths (synonyms: concrements, ${ }^{9,1}$ salivary stones, calculi $\left.{ }^{1,10}\right)$. All those reports proved one of the sialolithiasis theories, which describe a foreign body-induced sialolith formation. Despite the fact that in some cases the foreign bodies' are localized in the anterior/middle part of the duct, its migration to the intraglandular duct system is also possible and should be analyzed.

Retrograde passage of different foreign bodies into/inside the Wharton duct described in the recent publications: a $2.0 \mathrm{~cm}$ long barb-like metal body (which located at the posterior part of the Wharton's duct $)^{8}$ and $3.5 \mathrm{~cm}$ long wooden splinter ${ }^{11}$.

The purpose of our report is to present a unique case of a vegetal foreign body retrograde migration to the intraglandular duct of the submandibular gland with a developing of foreign body-induced sialolithiasis. Analysis of ultrasound examination, operation, and literature review are also highlighted. Our foreign body's case represents an intermediate stage of forming a complete sialolith around the foreign body nidus.

\section{CASE}

A 61-year-old Caucasian woman was referred to the Center of Maxillofacial Surgery and Dentistry with 4-day complaints: salivary colics and tissues enlargement in the area of right submandibular gland. Bimanual palpation revealed enlarged, firm and painful right submandibular gland. Upon the intraoral examination clear saliva milked from the orifices of both Whartons ' ducts. Sublingual mucosa also showed no signs of inflammation.

Preoperative ultrasonography was performed by an experienced ( 29 yrs) physician of ultrasound investigation (Lilia Savchuk) using $12-3 \mathrm{MHz}$ linear probe (model HD11 XE, Philips). Gray scale (synonym: B-mode) sonograms (Fig 1) showed 2-times enlarged right submandibular gland with a significantly dilated intraglandular duct system and $0.8 \times 0.3-\mathrm{cm}$ foreign body inside. Foreign body visualized as hyperechoic linear structure without artifact of acoustic shadowing typical for sialoliths.

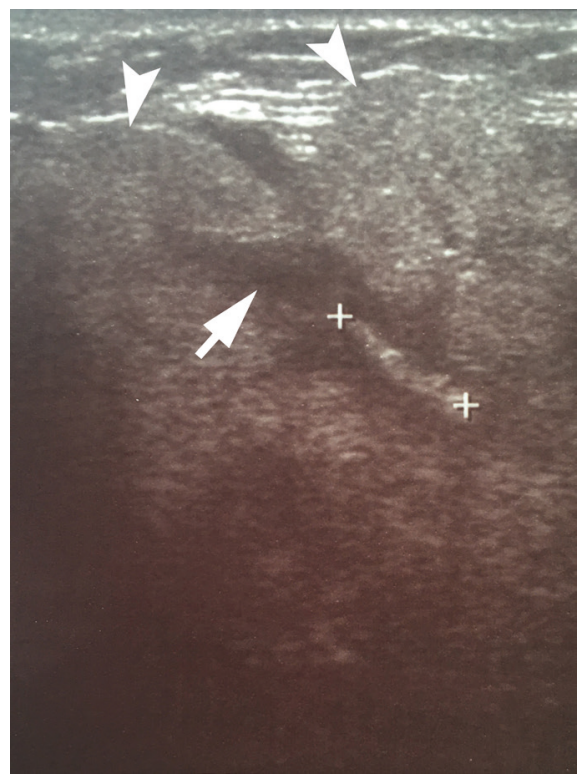

FIGURE 1. Preoperative gray scale sonogram shows an enlarged right submandibular gland (arrowheads) with a significantly dilated intraglandular duct system (arrow) and $0.8 \times 0.3$-cm foreign body inside, which is indicated by " + " calipers and visualized as hyperechoic linear structure without artifact of acoustic shadowing typical for sialoliths. 
Under the local anesthesia, a ductotomy in the posteriorpart of theright Wharton'sduct wasperformed and the foreign body was extracted. After removal, the foreign body undergone precise investigation by a surgeon (Oleksandr Nozhenko) which revealed a 0.8$\mathrm{cm}$ long green vegetal nidus (looked like a stem of a plant) with a multiple areas of attached calcifications (Fig 2). Intramuscular injections of ceftriaxone $1 \mathrm{~g} \times 2$ times per day and intraoral probiotics were prescribed simultaneously with rinsing by antiseptic solution during next 5 days after surgery. Post-operative period was smooth (i.e., uneventful recovery).

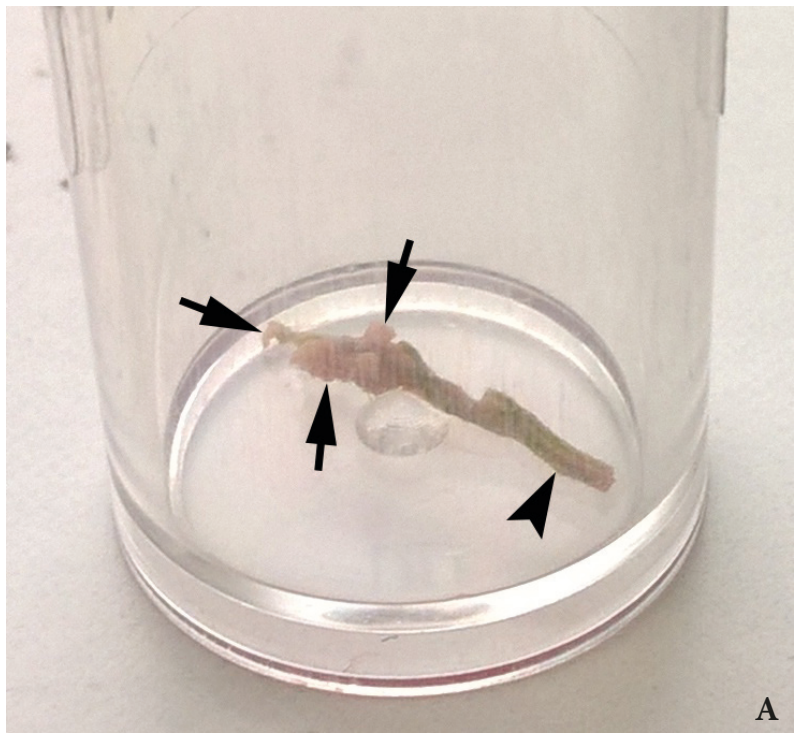

FIGURE 2. Foreign body after removal: A magnified view from different sides and multiple areas of attached calcifications (arrows).

\section{DISCUSSION}

Mechanical blockage of the ductal system and stasis of salivation describes the development of obstructive sialadenitis. If the foreign body intrusion was unrecognized by the patient and does not immediately cause complaints in a patient or patient received symptomatic treatment, the foreign body prolonged intraductal stay potentially can provoke formation of attached calcification around the foreign body's nidus and develop of foreign bodyinduced sialolithiasis.

Case studies indicate that foreign bodies can also penetrate parotid gland ducts without ${ }^{12}$ or with development of foreign body-induced sialolith ${ }^{13}$.

In contrary to smooth surface-foreign bodies, the bodies with irregular surface, like particles of the plants and fish bones, are more likely to transform into sialoliths.

Some of the particles originated from human body, like fingernail ${ }^{2,14}$ and hair ${ }^{5,15}$. Others were intruded upon eating the food, like fish bones. ${ }^{6,7,16-18}$ And a lot of foreign bodies of completely unexpected

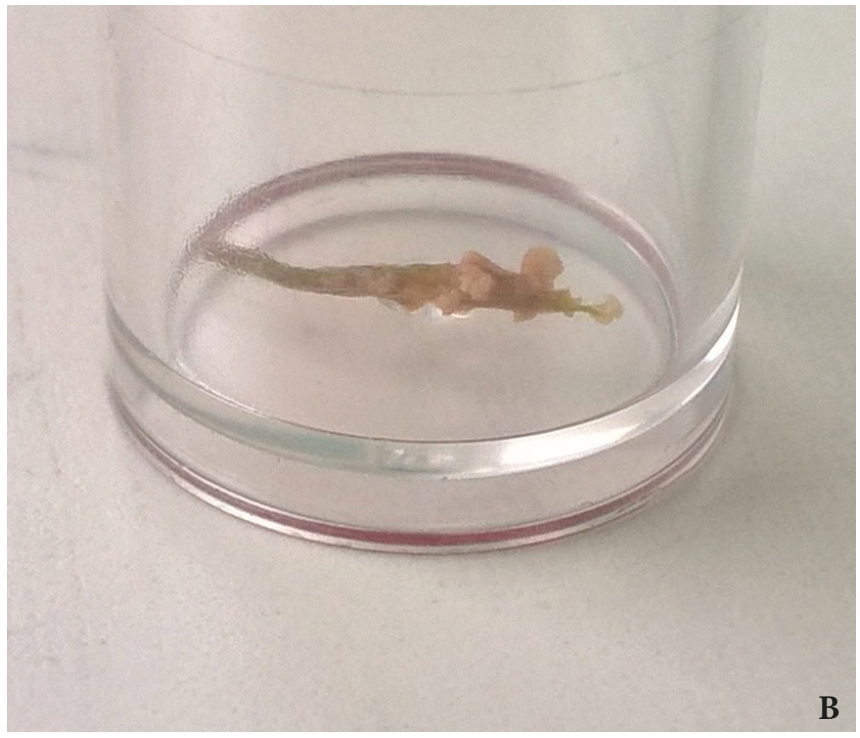

(A, B). A 0.8-cm long green vegetal nidus (arrowhead) with a rough surface origin like metal wire ${ }^{19}$, blade of grass ${ }^{20}$ or thorn ${ }^{4}$.

A thorough study of Loring W. Pratt showed the fundamental analysis of 15 literature sources from 1897 to $1968 .{ }^{10}$ Which revealed, among more than 37 cases with foreign bodies of the Wharton's duct $^{10}$, two patients with foreign bodies covered by calcifications $\mathrm{s}^{21,22}$. The oldest article reached the year 1897 when was reported a patient with sialitis (an old name of "sialadenitis") induced by a blade of grass without a stone formation. ${ }^{23}$

Reported, that foreign bodies can lead to the immediate insignificant complaints (the patients can feel an injection under the tongue at the moment of foreign body intrusion), ${ }^{1}$ and continue to behave as a "silent foreign body" even up to 12 months.

In some cases even a $3.5 \mathrm{~cm}$ long thin wooden splinter can migrate to the posterior part of the Wharton's with signs of obstructive sialadenitis but without sialolith formation around foreign body even after the 18 months of complaints. ${ }^{11}$ In other cases a prolonged foreign body intraductal stay can lead to the development of foreign bodyinduced sialolithiasis. As during the period of an 
intraductal localization of some foreign bodies with a rough surface, the salivary stones are formed by the precipitation of calcified structures around a foreign body-nucleus. We agreed with opinion of Derin et $\mathrm{al}^{18}$ who used another term for nidus - a scaffold. They describe intraductal fishbone which served as a scaffold for sialolth. ${ }^{18}$

In our opinion, a foreign body-induced sialolith formation is a more threatening condition for the course of obstructive sialadenitis. Because of a foreign body's volume increases due to the permanent precipitation of calcified structures around it. This fact provokes even severe blockage of the gland and stasis of the saliva. What also accelerate degenerative changes of the glandular tissue and increase the risk of exacerbation of the chronic obstructive sialadenitis.

Table 1 depicts completely different particles which served as a nidus upon foreign body-induced sialolith formation. To the table were gathered the cases which were published during last 124 years presenting the foreign body-induced sialolithiasis of the submandibular glands. The table was compiled based on our literature search and analysis of Loring W. Pratt, M.D. for the 1897-1968 period.

TABLE 1. Articles Describing the Foreign Body-Induced Sialoliths of the Submandibular Glands.

\begin{tabular}{|c|c|c|c|c|}
\hline \# & $\begin{array}{l}\text { Type of the Foreign Body } \\
\text { (i.e. Nucleus That is Made } \\
\text { of Foreign Body) }\end{array}$ & No. of Patients & Year of Publication & Title of the Article \\
\hline 1 & Blade of grass & 1 & 1937 & Salivary calculus containing a foreign body. ${ }^{21}$ \\
\hline 2 & Tooth brush bristle & 1 & 1959 & $\begin{array}{l}\text { Tooth brush bristle as a nucleus for calculus formation in } \\
\text { the hilum of the submaxillary gland. }{ }^{22}\end{array}$ \\
\hline 3 & $\begin{array}{l}\text { Vegetable matter with } \\
\text { calcium incrustation }\end{array}$ & 1 & 1967 & Unusual foreign body etiology of sialadenitis. ${ }^{24}$ \\
\hline 4 & Pine needle & 1 & \multirow{2}{*}{1968} & \multirow{2}{*}{ Foreign body of Wharton's duct with calculus formation. ${ }^{10}$} \\
\hline 5 & Broom straw & 1 & & \\
\hline 6 & Blade of grass & 1 & 1982 & $\begin{array}{l}\text { Submandibular salivary duct calculus secondary to a } \\
\text { foreign body. }{ }^{20}\end{array}$ \\
\hline 7 & Metal wire & 1 & 1984 & $\begin{array}{l}\text { A sialolithiasis formed around a metal wire in the } \\
\text { submandibular salivary duct. }{ }^{19}\end{array}$ \\
\hline 8 & Vegetal nidus & 1 & 2001 & Retrograde theory in sialolithiasis formation. ${ }^{3}$ \\
\hline 9 & Shrapnel & 1 & 2003 & $\begin{array}{l}\text { Shrapnel-induced sialolith-a rare etiology for sialadenitis: } \\
\text { Case report. }{ }^{25}\end{array}$ \\
\hline 10 & Thorn & 1 & 2005 & $\begin{array}{l}\text { Case of foreign body in Wharton's duct causing } \\
\text { silolithiasis. }\end{array}$ \\
\hline 11 & Fish bone & 1 & 2009 & Fish bone-induced sialolith. ${ }^{9}$ \\
\hline 12 & Facial hair & 1 & 2014 & Unusual case of a sialolith: a case report. ${ }^{15}$ \\
\hline 13 & Fish bone & 13 & 2014 & $\begin{array}{l}\text { Foreign body induced sialolithiasis treated by } \\
\text { sialoendoscopic intervention. }\end{array}$ \\
\hline 14 & Fish bone & 1 & 2015 & Fish bone induced sialolith in Wharton duct. ${ }^{18}$ \\
\hline 15 & Fish bone & 1 & 2018 & $\begin{array}{l}\text { Sialendoscopic removal of fish bone-induced sialoliths in } \\
\text { the duct of the submandibular gland. }{ }^{6}\end{array}$ \\
\hline 16 & $\begin{array}{l}\text { Vegetal nidus (stem of a } \\
\text { plant) }\end{array}$ & 1 & 2020 & $\begin{array}{l}\text { Foreign body retrograde migration to the intraglandular } \\
\text { duct of the submandibular gland with a developing } \\
\text { of foreign body-induced sialolithiasis: analysis of } \\
\text { ultrasonography, surgery, and literature published during } \\
\text { last } 124 \text { years. }\end{array}$ \\
\hline
\end{tabular}


The hair is perfectly described in 2009's sialoendoscopy report as a cause of obstructive sialadenitis of the submandibular gland. ${ }^{5}$ In 2014 the first case study presented a facial hair which served as a nidus for $\sim 6-\mathrm{mm}$ salivary stone formation. ${ }^{15}$

The same situation is with metallic foreign bodies. In some cases they are founded as a cause of obstructive sialadenitis without signs of sialolith formation, ${ }^{8}$ in others - sialolith forms around a metal wire ${ }^{19}$ or shrapnel ${ }^{25}$.

We supported the opinion of Sreetharan and Philip - ultrasound investigation may be a very good first line diagnostic modality. ${ }^{12}$ Upon ultrasonography sialoliths is usually visualized as hyperechoic semilunar bodies with an artifact of acoustic shadowing. Mucous plugs at ultrasound presented as a round shape isoechoic intraductal bodies without acoustic shadowing. ${ }^{26}$

2017 `s retrospective study of 659 salivary glands (486 submandibular and 173 parotid) revealed that sensitivity is of $94.7 \%$ and specificity of $97.4 \%$ for sonography in the patients with sialolithiasis. ${ }^{9}$

In our case the foreign body visualized as hyperechoic linear structure and the artifact of acoustic shadowing was not noted due to the partial calcifications around the vegetal nidus.
Summarizing the analysis of the published cases, the foreign body-induced sialolithiasis goes through 4 consecutive stages:

1. Calcium incrustations into foreign body (incrustations are visible only microscopically). ${ }^{24}$

2. Partially covered nidus (when calcifications are attached to different parts of the foreign body) (Fig 2). ${ }^{15}$ It can be considered as intermediate stage of sialolith formation.

3. Fully covered nidus (when cortex of calcifications covers the nidus from all sides).

4. Growth of sialolith 's cortex (this stage is pointed out based on the different sizes of sialoliths with the same size nidus).

And our case clearly shows that it's important to remember that those 4 stages should be distinguished. As upon the first stage, the organic foreign body can be completely invisible at X-ray/ computed tomography (in case of vegetal origin of foreign body) or showed no acoustic shadowing upon ultrasound.

Conclusion of two possible ways of pathological process development after intrusion of foreign body into the Wharton`s duct is represented in Figure 3.

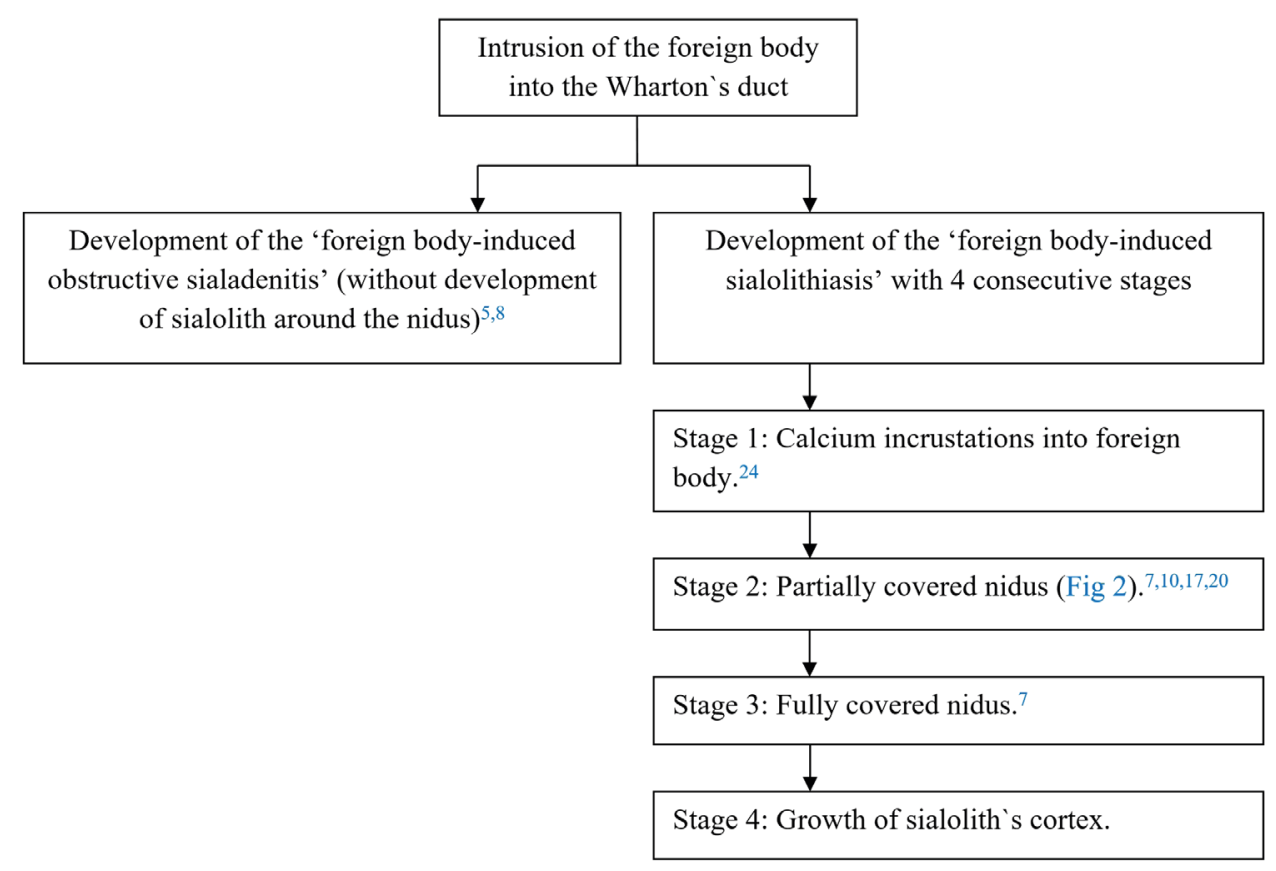

FIGURE 3. Flowchart displaying two possible ways of pathological process development inside the submandibular gland system after intrusion of the foreign body into the Wharton `s duct. 


\section{CONCLUSIONS}

Our paper summarizes the analysis of 28 cases with foreign body-induced sialolithiasis (27 cases from literature and a case of our team). Literature review which was based on the studies published during the last 124 years gave a possibility to classify the development of the 'foreign body-induced sialolithiasis' in 4 consecutive stages. Our case of the foreign body-induced sialolithiasis represents a second stage of this pathologic process when nidus is partially covered by calcinations. The report is heightened by the analysis of ultrasound features and macroscopic images.

\section{PATIENT CONSENT}

Not needed.

\section{CONFLICT OF INTERESTS}

The authors declare no conflict of interest.

\section{FUNDINGS}

No funding was received for this study.

\section{ACKNOWLEDGMENTS}

None.

\section{REFERENCES}

1. Tymofieiev OO. Manual of maxillofacial and oral surgery [Russian]. 5th ed. Kyiv: Chervona Ruta-Turs; 2012.

2. Modlin B. Foreign body (fingernail) as cause of acute submaxillary gland infection. Eye Ear Nose Throat Mon 1975;54(5):206-7.

3. Marchal F, Kurt AM, Dulguerov P, Lehmann W. Retrograde theory in sialolithiasis formation. Arch Otolaryngol Head Neck Surg 2001;127(1):66-8. https://doi.org/10.1001/archotol.127.1.66.

4. Bhavesh M. Case of foreign body in Wharton's duct causing silolithiasis. Indian J Otolaryngol Head Neck Surg 2005;57(4):322-3. http://dx.doi.org/10.1007/ BF02907699.

5. Ardekian L, Klain H, Peled M. Obstructive sialadenitis of submandibular gland due to foreign body successfully treated by sialoendoscopic intervention. J Oral Maxillofac Surg 2009;67(6):1337-9. https://doi. org/10.1016/j.joms.2008.12.059.
6. Iwai T, Sugiyama $S$, Hayashi $Y$, Oguri $S$, Hirota $M$, Mitsudo K, Tohnai I. Sialendoscopic removal of fish bone-induced sialolithsin the duct of the submandibular gland. Auris Nasus Larynx 2018;45(2):343-5. https:// doi.org/10.1016/j.anl.2017.03.010.

7. Xie L, Zheng L, Yu C, Yang C, Chen Z, Yun B, Kim E. Foreign body induced sialolithiasis treated by sialoendoscopic intervention. J Craniofac Surg 2014;25(4):1372-5. https://doi.org/10.1097/ SCS.0000000000000851.

8. Li P, Zhu H, Huang D. Detection of a metallic foreign body in the Wharton duct: a case report. Medicine (Baltimore) 2018;97(44):e12939. https://doi. org/10.1097/MD.0000000000012939.

9. Goncalves $M$, Schapher $M$, Iro $H$, Wuest $W$, Mantsopoulos K, Koch M. Value of sonography in the diagnosis of sialolithiasis: comparison with the reference standard of direct stone identification. $J$ Ultrasound Med 2017;36(11):2227-35. http://dx.doi. org/10.1002/jum.14255.

10. Pratt LW. Foreign body of Wharton's duct with calculus formation. Ann Otol Rhinol Laryngol 1968;77(1):88-93. http://dx.doi.org/10.1177/000348946807700109.

11. Chowdhary A, Kalsotra P, Parihar SS, Bhagat DR, Ali N. Rashid A. Foreign body in the Wharton's duct. JK Science 2005;7(2):61-2.

12. Sreetharan SS, Philip R. Unusual foreign body of parotid gland presenting assialolithiasis: casereportandliterature review. Case Rep Otolaryngol 2012;2012:367349. http:// dx.doi.org/10.1155/2012/367349.

13. Iwai $\mathrm{T}$, Izumi $\mathrm{T}$, Sugiyama $\mathrm{S}$, Watanabe $\mathrm{D}$, Kosugi Y, Mitsudo K. Sialendoscopic removal of gold filament thread-induced sialolith in the duct of the parotid gland. I Stomatol Oral Maxillofac Surg 2020:S2468-7855(20)30045-8. http://dx.doi. org/10.1016/j.jormas.2020.03.002.

14. Taneja M, Taneja MK. Foreign body Wharton's Duct. Indian J Otolaryngol Head Neck Surg 2011;63(3):3001. http://dx.doi.org/10.1007/s12070-011-0261-3.

15. Boynton TT, Lieblich SE. Unusual case of a sialolith: a case report. Oral Surg Oral Med Oral Pathol Oral Radiol 2014;117(1):e9-10. http://dx.doi. org/10.1016/j.0ooo.2012.03.020.

16. Abe K, Higuchi T, Kubo S, Oka M. Submandibular sialadenitis due to foreign body. $\mathrm{Br} J$ Oral Maxillofac Surg 1990;28(1):50-2. http://dx.doi. org/10.1016/0266-4356(90)90012-A.

17. Sato K, Umeno H. Fish bone-induced sialolith. Otolaryngol Head Neck Surg 2009;141(4):539-40. http://dx.doi.org/10.1016/j.otohns.2009.05.002.

18. Derin S, Sahan M, Kule M, Koseoglu S, Celik OI. Fish bone induced sialolith in Warthon duct. J Craniofac Surg 2015;26(7):e663-4. http://dx.doi.org/10.1097/ SCS.0000000000002075.

19. Takeda Y, Yahata C. A sialolithiasis formed around 
a metal wire in the submandibular salivary duct [in Japanese]. Shoni Shikagaku Zasshi 1984;22(3):712-5.

20. Watkins RM. Submandibular salivary duct calculus secondary to a foreign body. Br J Surg 1982;69(7):379. http://dx.doi.org/10.1002/bjs.1800690707.

21. Pilcher JA. Salivary calculus containing a foreign body. Arch. Otolaryngol 1937;26(5):531-3. http:// dx.doi.org/10.1001/archotol.1937.00650020585005.

22. Narayanan G. Tooth brush bristle as a nucleus for calculus formation in the hilum of the submaxillary gland. Indian Jour of Otol 1959;11(4):177-81. http:// dx.doi.org/10.1007/BF03047227.

23. Cosens C, Smith R. St. Bartholomew's Reports 1897;33:105.
24. Riccio FJ, Scavo VJ. Unusual foreign body etiology of sialadenitis. Arch Otolaryngol 1967;86(2):210-2. http:// dx.doi.org/10.1001/archotol.1967.00760050212019.

25. Ouellette AL, Slack CL. Shrapnel-induced sialolith-a rare etiology for sialadenitis: Case report. J Oral Maxillofac Surg 2003;61(5):636-7. http://dx.doi. org/10.1053/joms.2003.50123.

26. Cherniak OS, Fesenko II. Effectiveness of ultrasound in verification of the mucus plugs and sialoliths of the Wharton's duct. J Diagn Treat Oral Maxillofac Pathol 2019;3(5):144-53. http://dx.doi.org/10.23999/j. dtomp.2019.5.3. 


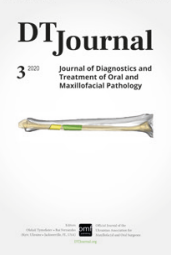

Images in Oral and Maxillofacial Surgery

Camilo Mosquera, DDS, Editor

\section{Large Mucocele in the Labial and Buccal Mucosa}

Beka Beridze \& Olha S. Cherniak

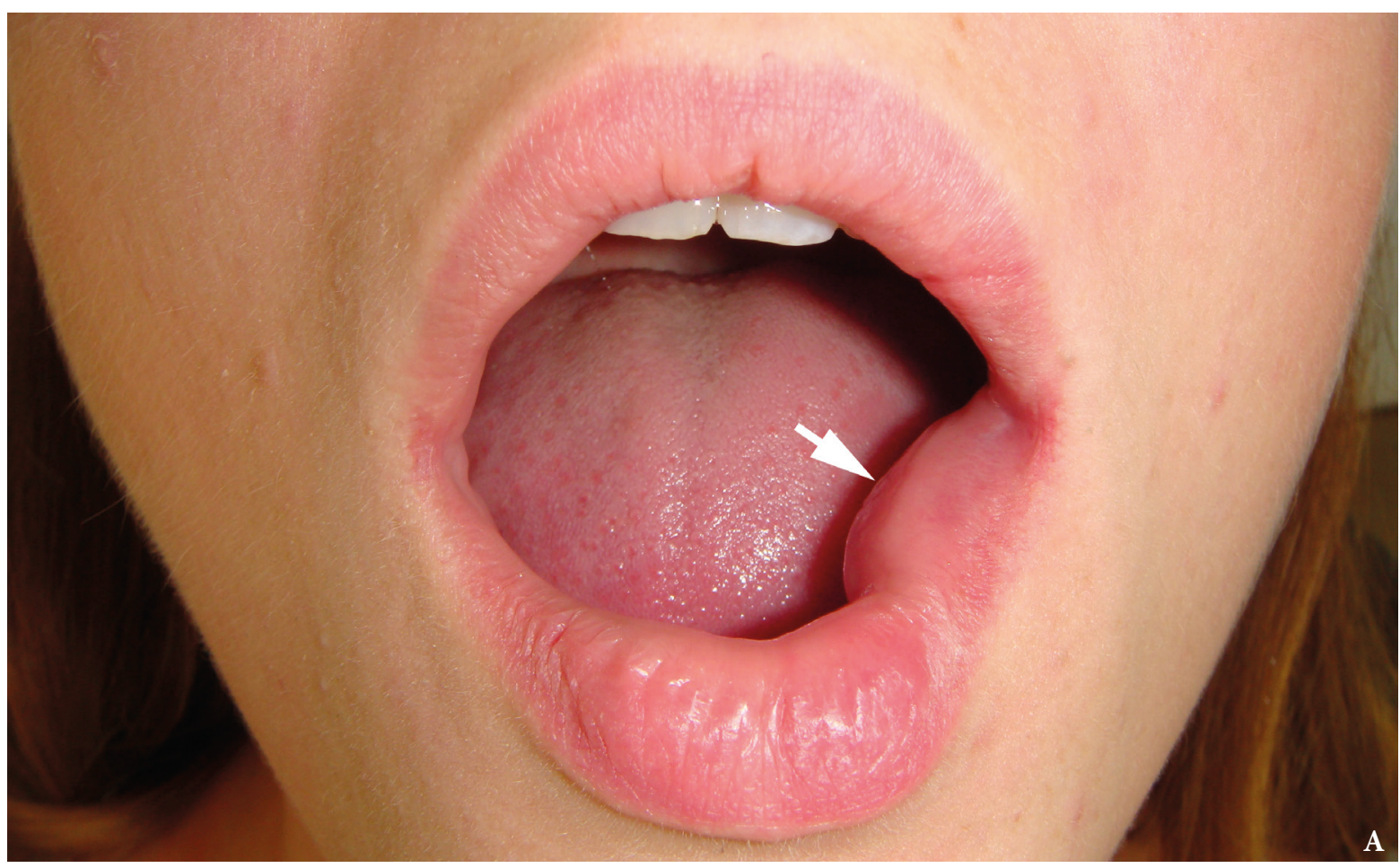

A 26-year-old woman presented to the maxillofacial surgery clinic with painless oval shape lesion (Panel A, arrow) arisen from the lower lip and extended to the buccal mucosa. According to the patient, the mass arose after repeated trauma (biting) of the mucosa (Panel B, arrowhead) approximately 3 months ago. Once the patient

a PhD, Assistant Professor, Department of Dentistry and Maxillofacial Surgery, Batumi Shota Rustaveli State University, Batumi, Georgia

PhD Student, Department of Maxillofacial Surgery, Shupyk National Medical Academy of Postgraduate Education, Kyiv, Ukraine (position at moment of material collection)

beni-denti@mail.ru

${ }^{b}$ Head, Department of Ultrasound, Regional Diagnostic Center, Kyiv Regional Clinical Hospital, Kyiv, Ukraine

cherniak.os@gmail.com
How to cite this article: Beridze B, Cherniak OS. Large mucocele in the labial and buccal mucosa. J Diagn Treat Oral Maxillofac Pathol 2020;4(3):60-1.

Paper received 10 February 2020

Accepted 11 March 2020

Available online 31 March 2020

https://dx.doi.org/10.23999/j.dtomp.2020.3.3

(C) 2020 OMF Publishing, LLC. This is an open access article under the CC BY license (http://creativecommons.org/licenses/by-nc/4.0/). 

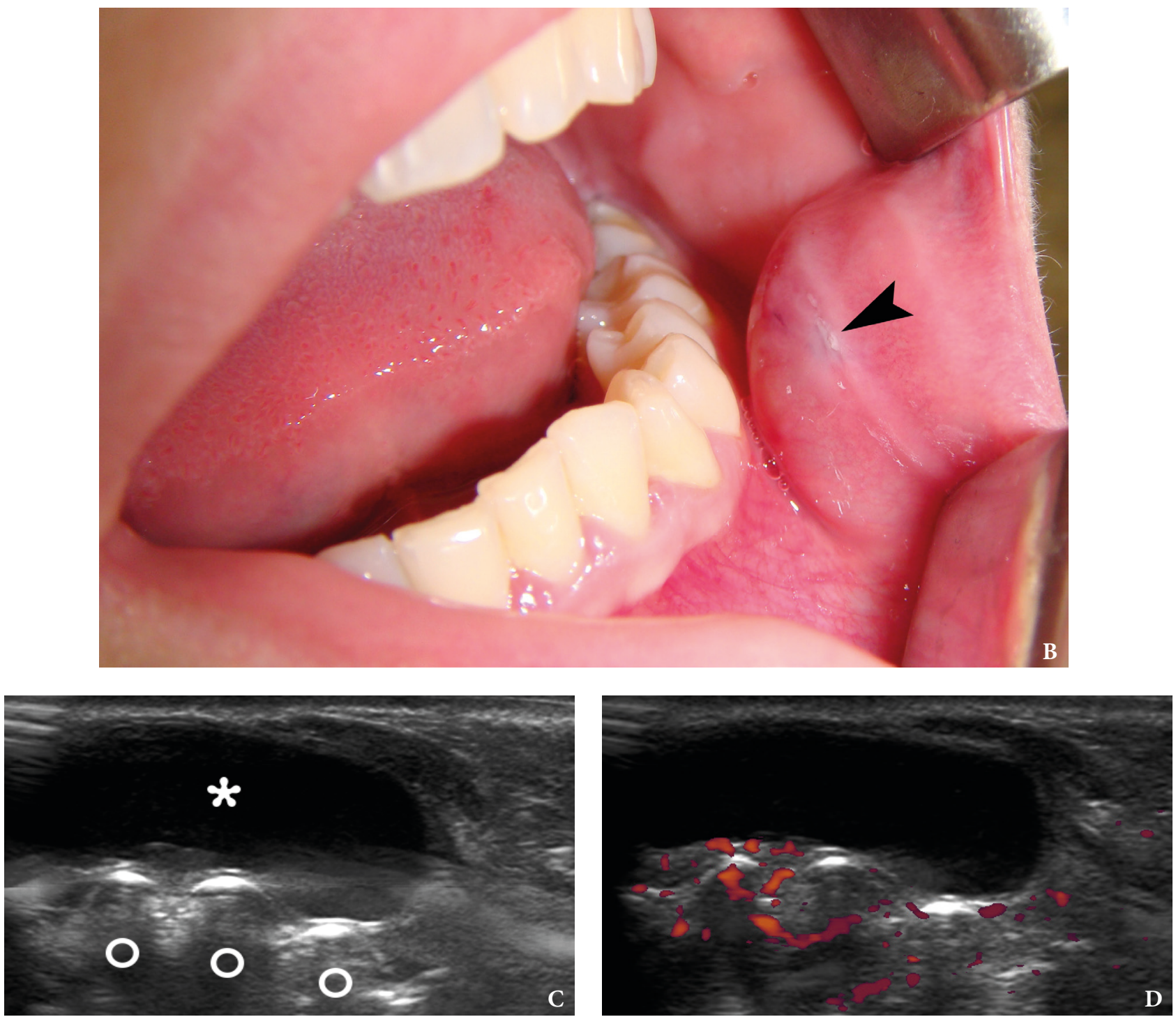

noted that when she bit the mass, it's emptied, but then began to grow again. Upon intraoral examination the lesion measured $1 \times 1.8 \mathrm{~cm}$ in size. Palpation showed its soft and spongy texture. No bluish pattern of the surface was noted. B-mode (Panel C) and power Doppler (Panel D) ultrasound demonstrated cystic, avascular lesion measuring $1.71 \times 0.92 \mathrm{~cm}$ with echogenic content (asterisk), no signs of echogenic debris, and distinct margins. Acoustic shadowing behind the hyperechogenic vestibular surface of the lower teeth is labeled by circles. The depth of the cropped sonograms is $1.56 \mathrm{~cm}$.

Mucocele of the oral cavity (synonyms: oral mucocele, mucous cyst, retention cyst, retention cyst of the minor salivary gland, mucous retention cyst) is a cystic lesion of the minor salivary gland due to its duct alternation/inflammation and subsequent accumulation of saliva. Differential diagnostics of mucocele is usually performed with other similar oral masses: lipomas, lymphangiomas, and hemangiomas. Removal of mucocele includes the excision of mucous cyst associated overlying mucosa, own glandular tissue and other minor salivary glands which are visualized in the wound. Histopathologically, two types of oral mucocele are distinguished: retention and the more often, extravasation variant.

Summarizing, despite the majority of mucocele cases presented with mucosa surface color ranged from deep blue to light blue, our case clearly shows a mucocele with a pink color of mucosa above. Recurrence is a complication usually associated with a violation of the operation technique. - DTJournal 


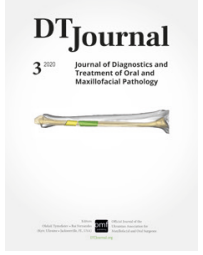

Images in Oral and Maxillofacial Surgery

Camilo Mosquera, DDS, Editor

\section{| Giant Parotid Pleomorphic Adenoma}

Valentyn H. Demidova, \& Vasyl A. Rybak

\begin{abstract}
A 49-year-old woman was referred to the maxillofacial surgery center with a gigantic mass (Panels A, arrow) in the right parotid area. Patient noticed mass's appearance 3 years ago with painless rapid growth during last year. No loss of function of the facial muscles was noted. No pathologic lymph nodes were also noted clinically and on the multi-slice computed tomography (MSCT), which revealed a large mass with lobulated borders in the right parotid area, displacing masseter muscle and upper portion of the sternocleidomastoid muscle. Pre- (Panels B and D) and post-contrast (Panels $\mathrm{C}$ and E) MSCT was performed according to the radiological protocol. Axial scans of the contrast-enhanced MSCT (Panels C and E) clearly demonstrate the polymorphic structure of the mass helping establishing the diagnosis of parotid pleomorphic adenoma.

Pleomorphic adenoma is a benign encapsulated tumor with a cellular polymorphism due to which this tumor is also named as a "mixed tumor." Very often these tumors have incomplete/'not true' capsule with a finger-like extensions into the glandular tissue. This anatomical feature requires from the surgeons to avoid a tumor's enucleation and perform the partial/total resection of the surrounding parotid tissue (parotidectomy)
\end{abstract}

\footnotetext{
${ }^{a}$ Oral Surgeon, Center of Maxillofacial Surgery and Dentistry, Kyiv Regional Clinical Hospital, Kyiv, Ukraine

valentyn.demidov@ukr.net

${ }^{b} \mathrm{PhD}$, Oral Surgeon; Head, Center of Maxillofacial Surgery and Dentistry, Kyiv Regional Clinical Hospital, Kyiv, Ukraine (position at moment of material collection)

rybak.jaws@gmail.com
}

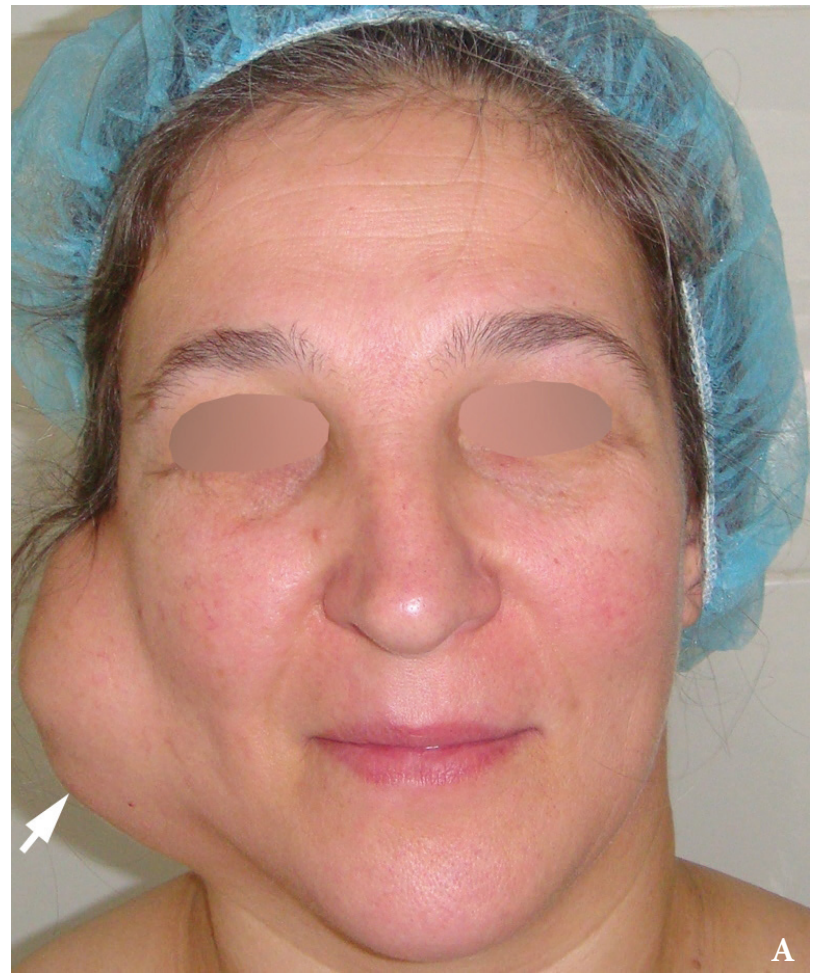

together with a mass. In cases of intratumoral localization of some branches of a facial nerve, the partial/total facial nerve sacrifice is indicated.

How to cite this article: Demidov VH, Rybak VA. Giant parotid pleomorphic adenoma. J Diagn Treat Oral Maxillofac Pathol 2020;4(3):62-3.

Paper received 12 January 2020

Accepted 10 February 2020

Available online 31 March 2020

https://dx.doi.org/10.23999/j.dtomp.2020.3.4

(c) 2020 OMF Publishing, LLC. This is an open access article under the CC BY license (http://creativecommons.org/licenses/by-nc/4.0/). 

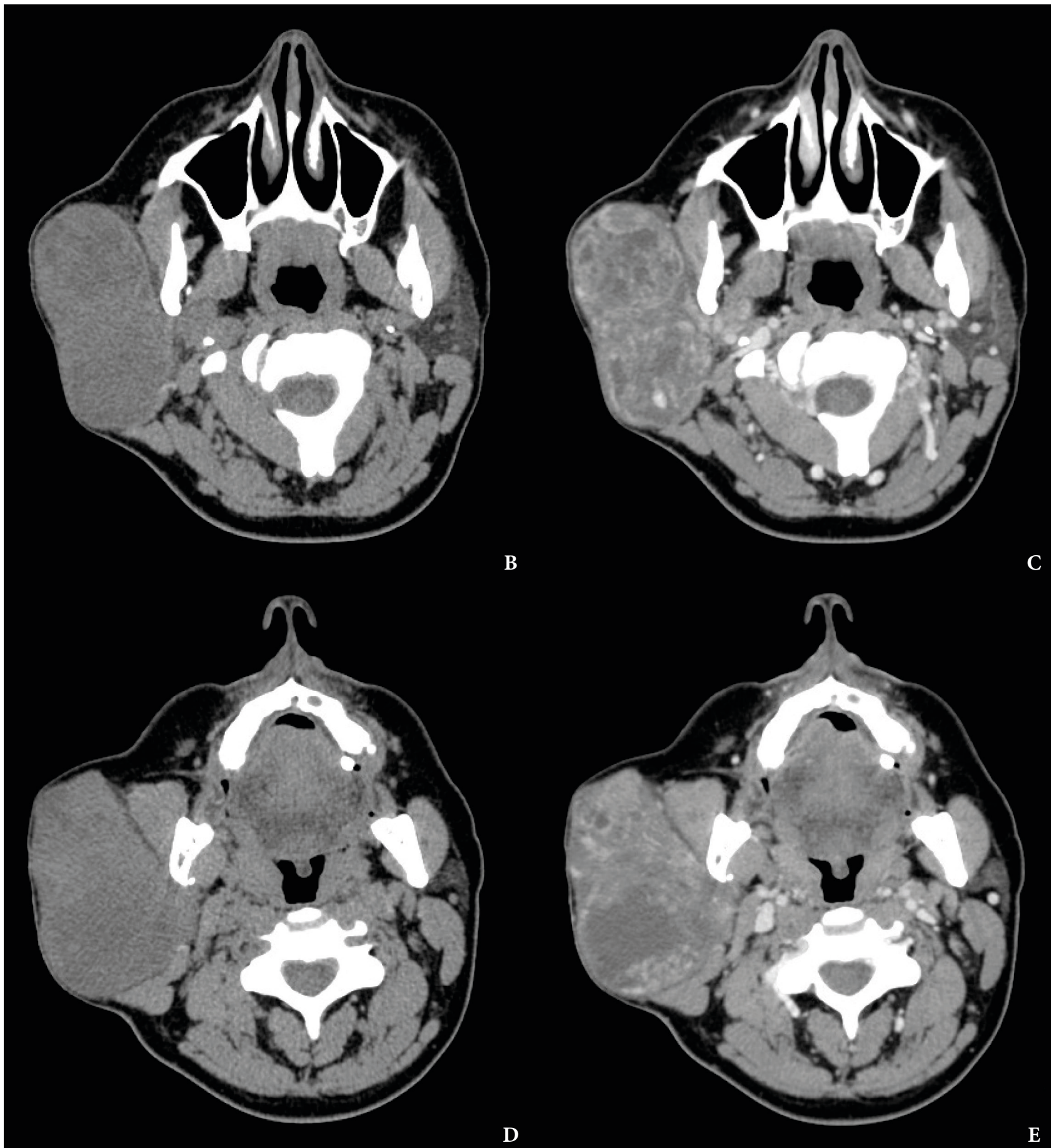

Such a radical treatment helps to reach two tasks: to avoid recurrence and to avoid possible malignant transformation of the recurrent pleomorphic adenoma.

The gigantic mass was removed under general anesthesia simultaneously performing right total parotidectomy with facial nerve preservation. The histopathology report proved the preoperative diagnosis.

The reported case supports the world statistics of this type of tumors: female predilection, most commonly occur in the parotid glands, mostly in its superficial lobe. - DTJournal 


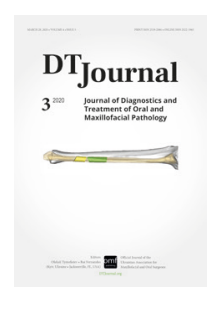

Post Scriptum Editorial

\section{Joining Forces of Two North American Associations}

\author{
levgen I. Fesenko
}

In the 75 years of its existence, it has continued to grow along with the specialty to become the premier journal in its field. ${ }^{1}$

-Daniel M. Laskin

Professor and Chairman Emeritus, United States

Readers of one the most famous professional publications, the Journal of Oral and Maxillofacial Surgery (JOMS), could notice that from January issue of 2020 the emblem of the American Association of Oral and Maxillofacial Surgeons (AAOMS) on the cover page joined the emblem of the Canadian Association Oral and Maxillofacial Surgeons (CAOMS).

After the 77 years of JOMS existence, which included 4-step gradual evolution of its title, ${ }^{1}$ the new journal's step included the joining efforts of two main professional non-profit organizations of the United States and Canada.

Till 2020, the Editorial Board page of the JOMS had one position, namely in the International Editorial Board section, for the professionals from Canada. During last 12 months, the position is led by David A. Walker, ${ }^{2}$ DDS MS, FRCD(C), Dip ABOMS, FADSA who serves as Assistant Professor, University of Toronto and who made an enormous contribution

Managing Editor, DTJournal.org; Kyiv, Ukraine

i.i.fesenko@dtjournal.org

How to cite this article: Fesenko II. Joining forces of two North American associations on pages of the Journal of Oral and Maxillofacial Surgery. $J$ Diagn Treat Oral Maxillofac Pathol 2020;4(3):64. to the CAOMS.

Thanks to the new step, in January 2020 a new founding position appeared, CAOMS - JOMS Liaison, which is led by Carl Bouchard, DMD, MSc, FRCD(C) from Québec, Canada. ${ }^{2}$ Term "Liaison" originated from French and now means a communication or cooperation which facilitates a close working relationship between people or organizations. ${ }^{3}$ Dr. Bouchard serves both as a reviewer of the JOMS during almost a full last 11 years, and an Associate Professor of Oral and Maxillofacial Surgery at Laval University. ${ }^{4}$ Thus Dr. Bouchard, knowing all publication's traditions of the JOMS and carrying surgical experience of the francophone region of Canada, will definitely help journal to reach the new highs of impact factor number and potentiate the journal's science. Moreover, his experience as author in 26 English-/French-language publications (including 6 book chapters), which permanently make an impact on the global development of oral and maxillofacial surgery, will help to grow the JOMS and both associations. ${ }^{5}$

We deeply believe that fusion of traditions and advantages of two great communities on pages of one journal (with 2018 impact factor 1.781) shows a great example for other journals and will significantly potentiate the results and growth of the specialty.

\section{REFERENCES}

1. Laskin DM. The history of the Journal of Oral and Maxillofacial Surgery. J Oral Maxillofac Surg 2018;76(10):2046-50. https://doi.org/10.1016/j. joms.2018.05.036.

2. Editorial Board page. J Oral Maxillofac Surg 2020;78(1):A2. https://doi.org/10.1016/S02782391(19)31264-9.

3. Hobson A. The Oxford dictionary of difficult words. 1st ed. Oxford: Oxford University Press; 2004.

4. LinkedIn: Carl Bouchard [document on the internet]; [cited 2020 Mar 26]. Available from: https:// ca.linkedin.com/in/carl-bouchard-a2b58184.

5. Spécialistes en chirurgie buccale et maxillo-faciale [document on the internet]; [cited 2020 Mar 26]. Available from: https://www.maxilloquebec.com/specialistes.

Paper received 10 March 2020

Accepted 22 March2020

Available online 31 March 2020

https://dx.doi.org/10.23999/j.dtomp.2020.3.5

(C) 2020 OMF Publishing, LLC. This is an open access article under the CC BY license (http://creativecommons.org/licenses/by-nc/4.0/). 


\section{TANTUM VERDE}

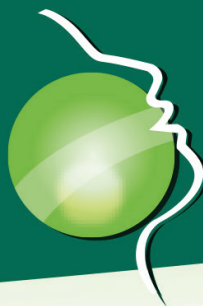

QUICK RELIEF FROM PAIN AND INFLAMMATION IN THE MOUTH AND THROAT'

\section{AN INTEGRAL COMPONENT OF THE TREATMENT OF PAIN AND INFLAMMATION IN THE ORAL CAVITY IN 60 COUNTRIES WORLDWIDE! ${ }^{2}$}

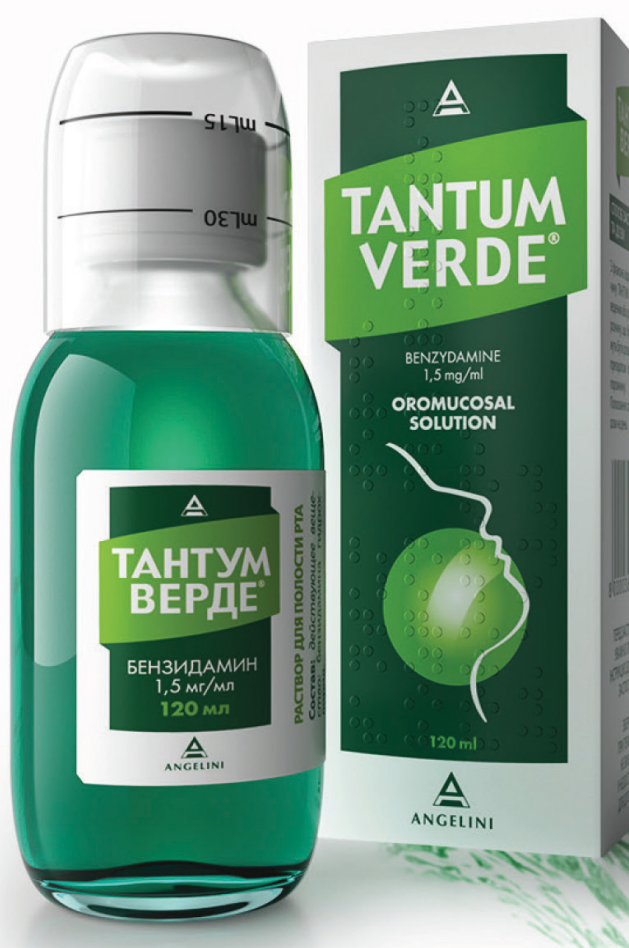

Reg. № UA/3920/01/01

\section{LOCAL ANESTHETIC AND ANTI-INFLAMMATORY EFFECT}

\section{- JAWS} FRACTURES ${ }^{3}$

- IMPLANTS PLACEMENT ${ }^{4}$

- WOUNDS OF ORAL CAVITY5
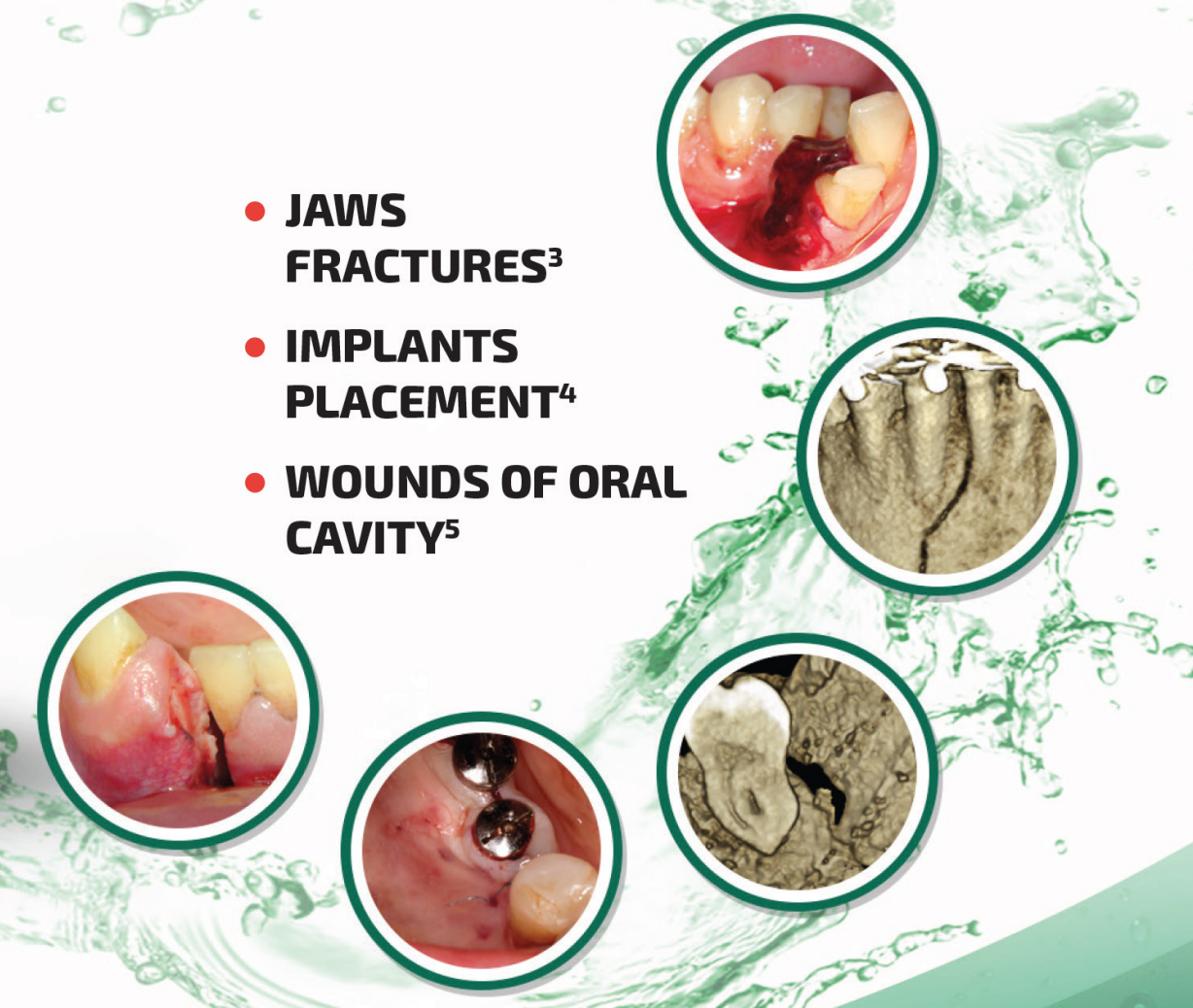

NAME OF THE MEDICINAL PRODUCT. Tantum Verde $0.15 \%$ mouthwash. QUALITATIVE AND QUANTITATIVE COMPOSITION. Each $100 \mathrm{ml}$ contains: active ingredient: benzydamine hydrochloride $0.15 \mathrm{~g}$ (equivalent to $0.134 \mathrm{~g}$ of benzydamine). Therapeutic indications. Treatment of symptoms such as irritation/inflammation including those associated with pain in the oropharyngeal cavity (e.g. gingivitis, stomatitis and pharyngitis), including those resulting from conservative or extractive dental therapy. Posology and method of administration. Pour $15 \mathrm{ml}$ of Tantum Verde mouthwash into the measuring cup, $2-3$ times per day, using it either at full concentration or ailuted. If diluted, add $15 \mathrm{ml}$ of water to the graduated cup. Do not exceed the recommended dosage. Contraindications. Hypersensitivity to benzydamine or to any of the excipient. PHARMACOLOGCAL PROPERIIES. Pharmacodynamic properties. Pharmacotherapeutic group: Stomatologic drugs: other agents for local oral treatment, AIC code: AOTAD2. Cinical studies demonstrate that benzydamine is effective in relieving suffering from locallsed irritation of the mouth and pharynx. In addition, benzydamine possesses a moderate local anaesthetic effect. Pharmacokinetic properties. Absorption. Absorption through the oropharyngeal mucosa is demonstrated by the presence of measurable quantities of benzydamine in human plasma. These levels are insufficient to produce systemic effects. Distribution. When applied locally, benzydamine has been shown to accumulate in inflamed tissues where it reaches effective concentrations because of its capacity to penetrate the epithelial lining. Information about medicines. Information for health care professionals for use in professional activities.

1 1нструкцін для медичного застосування лікарського засобу Тантум Верде

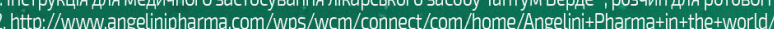

3. Тимофеев А.А. и др. "Особенности гигиены полости рта для профилактики воспалительных осложнений при переломах нижней челюсти". Современная стоматология 2015; (75):52-8.

4. 4,5. Tymofieiev 0.0. et al"Prevention of inflammatory complications upon surgeries in maxillofacial region". J Diagn Treat Oral Maxillofac Pathol, 2017; 1:105-12.

Clinical and CT images are courtesy of: Ievgen Fesenko (Department of Oral \& Maxillofacial Surgeny, PHEI "Kyiv Medical University," Kyiv, Ukraine), Oleg Mastakov ("SCIEDECE-Scientific Center of Dentistry \& Ultrasound Surgery" Kyiv, Ukraine) 